\title{
Arthur Neiva e a 'questão nacional' nos anos 1910 e $1920^{*}$
}

\section{Arthur Neiva and the 'national question' in the 1910s and 1920s}

\section{Vanderlei Sebastião de Souza}

Doutorando em História das Ciências pela Casa de Oswaldo Cruz/Fiocruz Rua Cardeal Leme, 125/s.402 20240-012 - Rio de Janeiro - RJ - Brasil vanderleidesouza@yahoo.com.br

Recebido para publicação em fevereiro de 2009. Aprovado para publicação em abril de 2009.
SOUZA, Vanderlei Sebastião de. Arthur Neiva e a 'questão nacional' nos anos 1910 e 1920. História, Ciências, Saúde Manguinhos, Rio de Janeiro, v.16, supl.1, jul. 2009, p.249-264.

Resumo

Com o objetivo de analisar as interpretações e os diagnósticos sobre o Brasil elaborados pelo cientista e escritor Arthur Neiva entre as décadas de 1910 e 1920, especialmente a partir de suas crônicas literárias e do relatório da expedição científica realizada ao interior do Brasil em 1912, destaco suas críticas contra a mentalidade das elites dirigentes e dos homens de letras, sobretudo pela falta de ação política, pelo apego à imitação das ideias e ao uso exagerado da retórica bacharelesca - considerados por ele os principais responsáveis pelo atraso cultural e político do país. Analiso também a maneira como Arthur Neiva lidou com a questão racial e os dilemas da formação nacional, tema considerado, no início do século XX, de fundamental importância para a compreensão da realidade e do destino do Brasil no chamado 'concerto das nações'.

Palavras-chave: Arthur Neiva; história intelectual; nação; identidade nacional.

Abstract

The article analyzes the interpretations and diagnoses of Brazil developed by scientist and writer Arthur Neiva in the 1910s and 1920s, focusing especially on his literary crônicas and his report on the 1912 scientific expedition to the interior of Brazil. I highlight the author's criticisms of the mentality of the governing elite and men of letters, especially their failure to take political initiative, their penchant for imitating ideas, and their exaggerated use of pretentious rhetoric, which Neiva believed to be the main culprits behind Brazil's cultural and political backwardness. I also analyze how Neiva addressed the race issue and the dilemma of nation building, which in the early twentieth century was considered a theme of prime importance in understanding Brazil's reality and destiny within the so-called concert of nations.

Keywords: Arthur Neiva; intellectual history; nation; national identity. 
$\mathrm{U}$ ma das características mais marcantes da tradição intelectual brasileira, sobretudo da geração que se formou na passagem do século XIX para o XX, foi um intenso desejo de intervir no processo de formação da vida política e social do país. Como bem destacou o historiador Nicolau Sevcenko (1999), nas primeiras décadas do século XX ensaístas, literatos, médicos e cientistas desenvolviam a atividade intelectual como missão política ou como 'ação pública', voltada para reforma e transformação efetiva da realidade nacional, e viam-se como coordenadores do processo de mudança em curso. Os intelectuais brasileiros repensavam o país, segundo Sevcenko (p.232), "como se seu olhar estivesse postado no próprio centro de decisões, calculando suas possibilidades, medindo seus limites reais". Desse esforço obstinado por reinventar a nação resultou um conjunto de representações que instituíam problemas, imaginavam soluções e acalentavam diferentes sonhos e projetos em relação ao futuro do Brasil. De maneira geral, a intelectualidade brasileira desse período dividia-se entre aqueles que voltavam seus olhos para o continente europeu - com vistas a modernizar, civilizar e integrar a sociedade de acordo com o ideário propagado pelas tradições europeias - e outros que procuravam compreender o país em seus próprios termos, investindo contra o modismo e a imitação das ideias (Oliveira, 1990; Herschmann, Pereira, 1994; Sevcenko, 1999).

Como integrante dessa geração, o cientista e escritor Arthur Neiva (1880-1943) não se fez ausente do debate que visava diagnosticar os males que impediam o desenvolvimento e a ascensão do Brasil no chamado concerto das nações. Além da atuação como cientista de laboratório, no Instituto de Manguinhos e, posteriormente, no Instituto Biológico de São Paulo, Neiva se caracterizou também como homem público ${ }^{1}$, um reformador social envolvido tanto com o mundo da ciência quanto do estritamente político, tendo atuado como interventor federal na Bahia durante o governo provisório de Getúlio Vargas e como deputado federal da Constituinte de 1933-1934 e da legislatura de 1934-1937. ${ }^{2}$ Pode-se dizer que Neiva foi intelectual híbrido que, assim como muitos de sua geração, se proclamava um homem de letras responsável por traçar os caminhos da nação. De outro lado, embora se visse como livre-pensador, pode ser caracterizado também como parte da intelligentsia nacional, tendo em vista sua forte ligação com o Estado brasileiro e sua atuação na promoção do nacionalismo.

A despeito da trajetória multifacetada desse personagem, meu objetivo, neste artigo, restringe-se a analisar apenas um dos aspectos da sua biografia, o de intérprete do Brasil. Embora não tenha sido propriamente literato, visto que ele próprio não se reconhecia como tal, Neiva escreveu, no início dos anos 20, algumas crônicas literárias - publicadas no jornal O Estado de São Paulo e na Revista do Brasil - que lhe renderam tal reconhecimento. ${ }^{3}$ As principais delas foram reunidas, em 1927, no livro Daqui e de longe... crônicas nacionais e de viagem. Nesses textos, abordou uma variedade de temas, como as características do pensamento intelectual e científico brasileiro, o uso da língua inglesa e francesa no Brasil, a questão do café na economia nacional, a importância da prática do esporte para a saúde física, a censura à imprensa, as condições da educação nacional, a imigração e a questão racial no Brasil e nos Estados Unidos, além de descrever algumas de suas experiências em viagens ao exterior.

Para a realização deste artigo, utilizei como fonte documental, além dessas crônicas, parte da correspondência de Arthur Neiva com outros intelectuais brasileiros e o relatório 
da expedição científica ao interior do Brasil, que realizou em companhia do médico e sanitarista Belisário Penna, em 1912. Esse conjunto de documentos dá a perceber a preocupação do médico e escritor baiano com a construção da identidade nacional e com o futuro político e cultural brasileiro, elementos que exploro aqui ressaltando principalmente seu diagnóstico acerca da realidade e do destino do Brasil como nação.

É importante assinalar que, logo no início dos anos 20, quando suas primeiras crônicas foram publicadas na imprensa paulista, Arthur Neiva já era figura de destaque no cenário intelectual e científico brasileiro, tanto no Rio de Janeiro, onde adquiriu prestígio como cientista do Instituto Oswaldo Cruz, quanto em São Paulo, onde dirigira o Serviço Sanitário Paulista entre 1917 e 1919. A relação de Neiva com o círculo da emergente intelectualidade paulista também é dado relevante em sua trajetória. Além da amizade que mantinha com o historiador Affonso de Taunay e com o jornalista e empresário Júlio de Mesquita Filho, Neiva cultivou com Monteiro Lobato longa amizade e estreita identidade intelectual, como se constata em suas correspondências pessoais. ${ }^{4}$ Vale destacar que em torno das figuras de Affonso de Taunay, então diretor do Museu Paulista, Júlio de Mesquita Filho, proprietário do jornal O Estado de São Paulo e idealizador da Revista do Brasil ${ }^{5}$, e Monteiro Lobato, que viria a dirigir a Revista do Brasil entre 1918 e 1924, se constituiria uma geração de influentes intelectuais que compartilhavam projetos político-culturais para a nação (Luca, 1999, p.4547). Essa rede de relações formada por Neiva e a intelectualidade paulista, assim como sua própria relação com o estado de São Paulo, transformar-se-ia, aliás, em influências centrais em seu modo de conceber a realidade e de propor soluções para os problemas nacionais.

\section{A imitação das ideias e a retórica parnasiana: os males do Brasil}

O historiador paulista Affonso de Taunay argumenta, em prefácio à obra Daqui e de longe, que Arthur Neiva tinha um "brasileirismo entusiasta", sendo que tudo quanto observava, comparava e relatava tinham por objeto a "aplicação aos nossos casos nacionais". Ainda segundo Taunay (1927), a sofreguidão com que Neiva procurava aproveitar "a lição dos grandes povos" para aplicar ao Brasil levava-o, às vezes, "ao desânimo fundo e a descrença da possível futura integração brasileira no rol das nações vanguardeiras da civilização" (p.5). A preocupação nacionalista de Neiva parecia transitar, desse modo, entre o otimismo e o pessimismo quanto ao futuro do Brasil, expressando uma das características mais marcantes de nossos intelectuais, a ambivalência.

O maior problema nacional, do ponto de vista de Arthur Neiva, não residia no povo brasileiro, como comumente aparecia nas páginas escritas por alguns de nossos homens de letras desse período. Neiva entendia que seria necessário mudar a mentalidade de nossos intelectuais e das elites dirigentes, que pouco faziam pelo progresso da nação, e chegou mesmo a destacar que o país só não se encontrava em piores condições porque o povo superava as elites governantes. "Quando penso no povo brasileiro - registra em uma de suas crônicas - sou sempre otimista; quando reflito na maioria das normas administrativas usadas no Brasil, não posso deixar de ser pessimista" (Neiva, 1927, p.193). Em sua compreensão, o povo brasileiro, embora acometido pela doença, pelo analfabetismo e 
pelo abandono por parte das autoridades políticas, teria o espírito do esforço e do sacrifício, faltando, para a integração e o desenvolvimento do país, antes, a capacidade de organização e de ação política das classes dirigentes.

A falta de ação pública e nossa tradição intelectual demasiadamente apegada à retórica e à imitação eram, em sua opinião, os principais elementos responsáveis pela pobreza de nossa mentalidade e pela incapacidade do Brasil em encontrar alternativas viáveis a seus problemas. Em vez do exercício efetivo da atividade pública e da ação política coordenada, denunciava ele, nossos administradores e intelectuais entregavam-se à atividade verbal, ao "pacientíssimo papel e ao tinteiro". Para nossos homens letrados, todas as crises políticas e sociais se resolveriam com o ato de escrever, falar, discursar, formular leis, regulamentos e regimentos, todos preparados em linguagem brilhante, cheios de minúcias, mas com conteúdo pouquíssimo eficiente e quase nenhuma ação. Em sua opinião:

É em consequência dessa mentalidade que os nossos legisladores, administradores e reformadores não se querem entregar à banalidade da ação, onde se malbarata o tempo. A atividade deve ser verbal; um dos campos de ação deve ser o existente entre o pacientissimo papel e o tinteiro. Escrever, falar, discursar ... . [A elite responsável por governar o país imagina] que a população cresce, a riqueza aumenta, a imigração vem, as finanças melhoram, todas as crises se resolvem ao influxo mágico da música de frase, o combustível de predileção da maioria dos administradores brasileiros e com o qual atestam as fornalhas da grande caldeira nacional, cujo manômetro ainda não atingiu à pressão necessária, porque isso, como diria o Geca, é como a lenha verde: dá fumaça bastante, alguma labareda, calor pouco e barulho muito...(Neiva, 1927, p.21).

Em suas crônicas, Arthur Neiva $(1927$, p.217) argumentava que a preocupação com a literatura, a poesia, o lirismo e a retórica era tão grande no país que até mesmo em nossas principais sociedades científicas, como a Academia Nacional de Medicina, a oratória servia como símbolo de distinção entre nossos cientistas. Além disso, frisava que outra demonstração de nossa inclinação parnasiana residia no fato de a Academia Brasileira de Letras ser procurada com empenho por nossos cientistas, médicos, engenheiros, generais e sacerdotes, que disputavam ardorosamente o cargo de orador da Academia. Em relação a esse aspecto, aliás, o historiador Sérgio Buarque de Holanda (1984) fazia coro às palavras de Neiva ao enfatizar, menos de uma década depois, o apego dos brasileiros à palavra escrita, ao bacharelismo e ao poder mágico das ideias. O brasileiro, explica o autor de Raízes do Brasil, seria menos afeito à especulação intelectual do que "o amor à frase sonora, ao verbo espontâneo e abundante, à erudição ostentosa, à expressão rara" (p.50-51).

Esse estilo retórico constituía, na verdade, uma característica que denotava, entre os brasileiros, signo de distinção intelectual, erudição e conhecimento da língua escrita. Segundo o historiador José Murilo de Carvalho (2002), o uso da retórica, no Brasil, era de tal modo significativo que logo se transformou em elemento de autoridade empregado pelos intelectuais para se legitimar perante seus pares (p.142). Essa sedução pela retórica e pelo parnasianismo, como apontam alguns autores, derivava em grande medida da tradição clássica portuguesa, sobretudo da larga formação escolástica que dominava o ensino nas escolas jesuíticas e, especialmente, na Universidade de Coimbra, em que se formou boa parte da elite intelectual brasileira a partir do final do século XVIII (Azevedo, 1963, 1994; 
Carvalho, 2002). Além do mais, como veremos em seguida, Neiva atribuía o legado retórico brasileiro não só à raiz escolástica portuguesa, mas também à tradição literária francesa.

Destaque-se ainda que Neiva faz parte de uma geração de intelectuais que, na passagem do século XIX para o XX, começaram a se especializar em diferentes carreiras científicas, sendo reconhecidos como 'homens de ciência' dedicados ao laboratório e ao serviço de experimentação e observação da realidade. Essa geração, como aponta a historiadora Dominichi Miranda de Sá (2006, p.14-15), além de defender um padrão mais especializado de formação e produção intelectual e científica, refutava a antiga geração de letrados formados sob a influência de conhecimento considerado exageradamente romântico, enciclopédico, beletrista e bacharelesco. Para os cientistas especializados, como era o caso de Neiva, boa parte da literatura de ficção produzida no Brasil não passava de atividade diletante, ocupada tão-somente com a beleza da forma, as fantasias e os variados gostos literários, sem nenhuma utilidade a apresentar à sociedade (p.16). Do ponto de vista pragmático e nacionalista de Neiva, como ele mesmo sugeria ao comentar a obra do amigo e escritor Afrânio Peixoto, a literatura brasileira poderia contribuir de modo mais efetivo se tratasse com mais frequência dos "episódios nacionais" (Neiva, 20 jul.1917).

Talvez as palavras que melhor sintetizem as concepções dessa nova geração, e que podem ser vistas como autoimagem de sua atuação, sejam estas do antropólogo Edgard RoquettePinto (23 mar. 1939, p.45), um dos principais representantes do novo grupo de intelectuais:

Venho das últimas gerações da monarquia. Assisti aos cinco anos às primeiras festas da República. Penso que o país deve um grande serviço à minha geração: foi a primeira a descrer das 'fabulosas riquezas' do Brasil, para começar a crer nas 'decisivas possibilidades do trabalho'. Recebemos a noção de que um moço bem nascido e bem criado não devia precisar trabalhar ... . Ouvimos ainda o eco dos eitos. Diziam-nos que nosso céu tem mais estrelas que os outros ... . Minha geração começou a contar as estrelas. E foi ver se era verdade que nos nossos bosques havia mais vida. E começou a falar claro aos concidadãos. Com minha geração, o Brasil deixou de ser um tema de lirismo.

Filhos dessa nova geração, tanto Roquete-Pinto quanto Arthur de Neiva compreendiam que, em vez da palavra pomposa e da cultura bacharelesca, sua geração deveria ser portavoz da ação pública e dos interesses da nação, atentando mais para o trabalho e a descrição da realidade do que para a imaginação romântica e fantasiosa que tanto impregnava a mentalidade nacional. De acordo com Neiva, o brasileiro era de tal modo seduzido pela "discurseira" e pelo lirismo, que a palavra era mais do que tudo, sendo boa parte de nossa atividade mental dispensada em descrever o maravilhoso ou em elaborar um mundo de fantasia que vai sempre além da intenção do escritor. Neiva (1927, p.18) sarcasticamente destacava em uma de suas crônicas:

Ao simples enunciado de vocábulos nós ouvimos a voz dos travões; vemos o azul das águas encapeladas, o ziguezaguear dos coriscos, a iminência do naufrágio, se um bom orador descreve uma tempestade. Certo que para um público inteligente e de qualquer raça a sensação seria a mesma e o resultado procurado pelo tribuno, mais ou menos parecido; a diferença, porém, é que nós vamos adiante, ultrapassamos a fantasia de quem ora. E, na tempestade, não nos limitamos a evocá-la, mas, sem querer, dela participamos e antes que o navio naufrague atiramo-nos à água, agarramos um salva-vidas e nadamos para a terra. Quando o discurso acaba, estamos cansados do esforço muscular desenvolvido pela natação... 
A crítica do cronista baiano dirigia-se, acima de tudo, ao culto que se fazia, no Brasil, à língua francesa e a sua tradição literária, a qual era por demais apegada à poesia, ao romance e à contemplação. Entre as autoridades brasileiras, lembrava Neiva, ainda era comum a convicção de que o francês era a língua universal e de que o mundo se resumia à França. Neiva incomodava-se com o fato de o Brasil envaidecer-se com a imitação que se fazia da França em vários aspectos de nossa cultura e, inconformado, questionava nossa condição de "satélite espiritual" e político daquela nação. Na crônica intitulada "Da língua francesa", ele enfatizava que o Brasil servira e prosseguia "servindo de ressonador para tudo quanto a França faz, nós somos o seu eco e tal função nos envaidece". Os homens de letras e os governantes, ele considerava, deveriam aprender a refletir a partir de suas próprias ideias, mirando exclusivamente os interesses nacionais (Neiva, 1927, p.26). Enquanto o Brasil cortejava as nações poderosas do mundo, "imitando-as graciosamente", argumentava, os vizinhos argentinos estavam atentos a seus próprios sons, aos interesses de sua nação. Em suas palavras, "essa confiança em si" que movia a nação argentina, "esse querer andar pelos próprios pés, numa ânsia de independência, foram devidos ao fato de nossa irmã do Sul ter se emancipado, mais cedo do que nós, da absorvente influência francesa" (p.27).

Por outro lado, Neiva não se furtava a formular ácidas críticas também contra a herança portuguesa, sobretudo quanto ao modo como o conhecimento era tratado no Brasil. O ataque à tradição lusitana, aliás, era uma constante na correspondência pessoal de Neiva, principalmente naquela mantida por longos anos com o escritor Monteiro Lobato, seu amigo e outro crítico mordaz do lusitanismo. Para ambos, a herança portuguesa era responsável pela "estupidez brasileira", pelo atrasado intelectual e político das classes dirigentes. Nas palavras de Neiva, "a burrice lusitana" havia sido transplantada para o Brasil do mesmo modo que fez Dom João VI com a sua corte". "E o mais interessante concluía Neiva - é que supomos ser o povo mais inteligente do mundo ... . A asnice nacional está como a última teoria de Einstein para o infinito: o espaço se dilata incessantemente numa velocidade incrível" (Neiva, 13 mar. 1934).

Neiva (1927, p.193-194) acreditava que, tal como a mentalidade portuguesa, a da maioria dos brasileiros estaria mais inclinada a acreditar no espetacular e no fantasioso do que na realidade e na verdade científica: "o atraso do Brasil tem sido devido ao desconhecimento do valor da ciência. O maravilhoso tem aqui muito maior influência do que a verdade científica". Nesse particular, afirmava ele em crônica publicada na imprensa paulista, o Brasil continuava sendo um fiel seguidor de Portugal, onde, em geral, as questões de ciência pouco interessavam (p.215). Conforme correspondência enviada a Monteiro Lobato, ainda nos anos 20, Neiva destacava: "A ciência é tudo no Brasil, porém, há ainda quem acredite muito mais no maravilhoso. A herança portuguesa criou um depósito de chumbo nas células cerebrais dos seus descendentes, em geral somos burros de nascença e burros morreremos. O Brasil é o robusto filho de Portugal e poderá mudar seu nome com justiça para o de Portugalão" (Neiva, 21 jan. 1929).

Contudo, apesar desse arroubo de pessimismo contra o modo de pensar do brasileiro, Neiva acreditava que a atuação de cientistas como Oswaldo Cruz - já nos anos 20 considerado o grande mito da ciência brasileira (Brito, 1995) - e o modelo de ciência feita no Instituto de Manguinhos serviriam como exemplos de que a atividade científica era 
possível no país. Para isso, seria necessário mudar a mentalidade contemplativa de nossa elite dirigente e dos nossos intelectuais, fugindo sempre que possível dos modos francês e português de conceber o mundo, dos métodos e processos estrangeiros, que seriam, em sua opinião, inadequados a nosso meio. A imitação seria a causa fundamental de nosso insucesso no campo da ciência e do ensino, uma vez que "temos procurado, sobretudo, imitar, reproduzindo o que lemos, quando o essencial seria reformar levando em consideração nossas condições, afim de melhor atendermos nossas necessidades" (Neiva, 1927, p.208).

Também nesse aspecto pode-se dizer que Arthur Neiva estava sintonizado com forte tendência política do pensamento intelectual brasileiro que emergiu principalmente no pós-Primeira Guerra Mundial, o qual destacava a necessidade de se pensar o Brasil em seus próprios termos, de projetar soluções próprias para os problemas nacionais. ${ }^{6}$ Tomado pelo sentimento de que o modelo europeu de sociedade não mais servia como referência para construir a moderna nação tropical, esse movimento intelectual, fortemente caracterizado por nacionalismo nativo, buscou construir outras referências para projetar o futuro do Brasil, procurando livrar-se dos referenciais europeus que até então dominavam o pensamento das elites locais. Sustentada por essa 'força nativa', parte dos intelectuais visava reconfigurar a consciência nacional como meio de 'redescobrir' as especificidades que formavam a nação brasileira (Herschmann, Pereira, 1994, p.29).

De acordo com Neiva, uma das alternativas mais viáveis para reformar a sociedade e a nação passava pela educação, especialmente por uma nova educação da elite culta brasileira, o que criaria ambiente adequado ao desenvolvimento da ciência e de instituições científicas sólidas. Embora crítico da tradição intelectual que tudo explicava pela imitação, Neiva (1927, p.28) não deixava de ser ambivalente ao sugerir que substituíssemos o modo contemplativo de pensar do francês pelo pragmatismo do inglês. Segundo ele, lendo francês nós teríamos aprendido a absorver poesia, lendo inglês aprenderíamos a trabalhar para vencer; o sonhador se transformaria em homem de ação, os doutores e funcionários públicos formados em nossas escolas se transformariam em industriais e comerciantes de sucesso. A substituição da língua inglesa pela francesa, em nossas escolas e entre nossos letrados, seria, desse modo, alternativa para mudar a mentalidade dos brasileiros e para colocar a nação no trilho do desenvolvimento.

A despeito, portanto, de seu nacionalismo nativo, Neiva pode ser considerado americanista, assim como seu amigo Monteiro Lobato e outros intelectuais brasileiros do período. Sua viagem aos Estados Unidos, em 1910, e seu contato com a filosofia, a ciência e a literatura daquele país o teriam encantado de tal modo, que confessaria ter visto a França transformar-se em nação pequena e "chocha" perante a grandiosidade do gigante que se formava do outro lado do Atlântico, lugar onde residia a verdadeira "oficina de titãs". Segundo Neiva (1927, p.116), o Brasil havia ignorado os Estados Unidos exatamente por ter sido, por muito tempo, "vitima da superstição francesa". Lá, diz ele, teria encontrado "tudo o que se negava por aqui: ciência, idealistas, filantropia, arte, literatura, e, sobretudo, uma capacidade de organização verdadeiramente assombrosa".

Acreditava, ainda, que a imprensa escrita teria papel fundamental no processo de reforma nacional e que, considerando o fato de os brasileiros lerem quatro jornais por mês e nenhum livro, a ela caberia o "papel decisivo no orientar a marcha nacional" (Neiva, 1927, p.41). 
Já em 1918, informa sua correspondência pessoal, almejava criar um jornal que estivesse preocupado, acima de tudo, com a vida social e política do país. Em carta a seu amigo Sampaio, Neiva argumentava sobre o benefício que "um jornal matutino, de grande formato" poderia trazer para o Brasil, pois era-lhe inconcebível "que a nação continuasse a rolar sem que ninguém a desperte, a instrua, a oriente. Não é possível que um país de tanto futuro seja levado ao Deus dará, em momento tão decisivo para a coletividade humana". Um jornal desse porte poderia iniciar várias campanhas "em beneficio da nossa terra e da nossa gente, desde a questão do saneamento até a da redução dos impostos inconcebíveis que nos esmagam" (Neiva, 9 mar. 1918).

No início dos anos 30, com Azevedo Amaral, Neiva chegou a dirigir o jornal A Nação, vinculado à corrente tenentista. Contudo, devido a sua eleição como deputado federal pelo Partido Social Democrático (PSD) para a Assembleia Nacional Constituinte, em 1933, bem como ao tenso clima político que se instalou no país naquele momento, afastou-se da direção do jornal. Na verdade, Neiva sempre esteve ligado ao trabalho editorial, fosse como consultor, como da Revista do Brasil, onde dirigiu, ao lado de Roquette-Pinto, a seção Notas de Ciência, fosse como fundador de periódicos científicos, como o Boletim do Museu Nacional, que criou durante sua passagem como diretor da instituição, entre 1923 e 1927.

Assim como a maioria dos intelectuais brasileiros do período, Arthur Neiva entendia que a imprensa tinha um papel regenerador a cumprir, especialmente o de instruir as massas sequiosas por ouvir os juízos e a orientação dos homens de letras. Ao lado da literatura, como destaca o historiador Nicolau Sevcenko (1999, p.94-95), nesse período os jornais tornaram-se ferramenta fundamental, pela qual os intelectuais procuravam intervir na organização da vida social e política da nação. Descrente no poder de ação das elites políticas, Sevcenko explica que era através dos jornais que os intelectuais brasileiros procuravam exercer seu poder de tutela sobre larga base social, ansiosos por definir os caminhos por onde a nação deveria seguir sua marcha. Além do mais, vale destacar, como lembra Benedict Anderson (1989), que tanto a literatura quanto a imprensa exerceram papel central na organização dos discursos nacionais, uma vez que esses instrumentos permitiam construir uma consciência coletiva quanto à existência de identidades comuns que reuniam os indivíduos em torno da ideia de nação, de "comunidade política imaginada", como Anderson prefere chamar.

\section{A questão racial e a construção da identidade nacional}

A exemplo do que ocorria com a maioria dos intelectuais brasileiros da época, Neiva dispensou atenção à premente questão racial. Embora entendesse que os problemas brasileiros residiam, antes de tudo, no modo como as elites políticas e os intelectuais administravam o país, em alguns momentos Neiva enredava-se também em certos argumentos raciais ainda em voga no pensamento social brasileiro do início do século XX, o que o levava a empregar tais referenciais para pensar a nação e a construção da identidade nacional. De maneira geral, ao mesmo tempo que valorizava a identidade racial brasileira, sobretudo a do homem sertanejo, Arthur Neiva sugeria a imigração de europeus como fator positivo para o desenvolvimento do país e a formação da nacionalidade. 
Além de serem encontrados em suas crônicas, esses argumentos constam no relatório de viagem que preparou, com o médico e sanitarista Belisário Penna, durante a expedição científica ao interior do Brasil, realizada em 1912. Financiados pela Inspetoria de Obras Contra as Secas, ao longo de nove meses os viajantes e sua comitiva atravessaram os estados da Bahia, Goiás, Piauí e Pernambuco coletando informações sobre geografia, clima, fauna e flora da região, bem como dados sobre o quadro de doenças e as condições de vida da população sertaneja. Publicado em 1916 em Memórias do Instituto Oswaldo Cruz, o relatório transformou-se em importante documento que revelou o estado de miséria e abandono em que vivia a população do interior do país (Neiva, Penna, 1984). O conteúdo do relatório surtiu efeitos imediatos. Não apenas mobilizou parte da imprensa brasileira acerca de um Brasil praticamente desconhecido, como também se transformou em documento crítico contra a ineficiência do Estado quanto às necessidades mais elementares da população sertaneja, sobretudo no que dizia respeito à saúde, educação, habitação e transporte. ${ }^{7}$ Nesse extenso e minucioso relatório - que pode ser definido também como um verdadeiro 'retrato do Brasil' (Lima, 1999, 2007) - Neiva e Penna denunciavam a falsa imagem, criada ao longo do tempo, do interior do país. Em vez da riqueza exuberante, da existência de uma infinidade de minérios e de solo fértil, como os românticos poetas brasileiros imaginavam, o sertão se apresentava, aos olhos de Neiva e Penna, como realidade inteiramente diferente. Se fôssemos poetas, diziam eles no relatório de viagem:

escreveríamos um poema trágico, como a descrição da miséria, das desgraças dos nossos infelizes sertanejos abandonados, nossos patrícios. Os nossos filhos, que aprendem nas escolas que a vida simples de nossos sertões é cheia de poesia e de encantos, pela saúde de seus habitantes, pela fartura do solo, e generosidade da natureza, ficariam sabendo que nessas regiões se desdobra mais um quadro infernal, que só poderia ser magistralmente descrito pelo Dante imortal (Neiva, Penna, 1984, p.222).

A franqueza com que era descrita a vida do sertão certamente não agradava boa parte da população do litoral - como os próprios autores ressaltavam -, sobretudo das elites políticas e das oligarquias, que ignoravam as condições de vida da população sertaneja. Para Arthur Neiva e Belisário Penna (1984, p.222) era "um dever de consciência e de patriotismo" para com a nação denunciar o estado de miséria e abandono do homem do interior. Tal atitude evitaria que os jovens de hoje sofressem "a triste desilusão por que nós passamos quando, através dos livros e romances, havíamos imaginado o Brasil Central um país privilegiado". Nesse trecho, os cientistas de Manguinhos faziam claramente uma denúncia contra a descrição que os naturalistas e a literatura romântica do século XIX, especialmente de escritores como José de Alencar, Bernardo Guimarães e Franklin Távora, faziam do sertão e do sertanejo, idealizando a paisagem natural, suas riquezas e a relação harmoniosa do homem com o meio.

O retrato do sertão esboçado pelos viajantes transformou-se também em relevante documento contra o determinismo racial e climático. O problema que afligia a população do sertão, afirmavam, não dizia respeito ao clima ou à raça, mas sim à doença e às péssimas condições de vida a que estava submetida, sendo habitual equívoco revelar o Nordeste como lugar inaproveitável para viver e o "povo sertanejo" como indolente - "a ausência de esforço e iniciativa dessa pobre gente, é proveniente do abandono em que vive, e da 
incapacidade física e intelectual, resultante de moléstias deprimentes e aniquiladoras" (Neiva, Penna, 1984, p.221). Quando saudáveis e bem alimentados, argumentavam numa das passagens marcantes do relatório, os vaqueiros se apresentavam como "tipos dignos de toda a simpatia e admiração". Só quem os viu vaquejar "poderá avaliar a extraordinária energia física e inigualável coragem que possuem; eles demonstram que aquela gente tem energias capazes dos maiores feitos e até hoje, nada vimos em arrojo, sangue frio, resistência e agilidade, comparáveis às façanhas daqueles homens" (p.167).

Embora não haja, no relatório, referências diretas à obra Os sertões, de Euclides da Cunha, Neiva e Penna parecem querer repetir-lhe o argumento "O sertanejo é antes de tudo um forte" (Cunha, 1952, p.101). Ao descrever um grupo de sertanejos que os acompanhou durante um longo trecho da expedição, realizada desde Juazeiro, na Bahia, até o sertão de Goiás, Neiva e Penna (1984, p.220) argumentam:

\begin{abstract}
Apesar de rústicos e analfabetos quase todos serviram-nos com dedicação, concorrendo eficazmente para a marcha excepcional que realizamos. Eram eles os primeiros que se levantavam, geralmente às quatro e meia da madrugada, às vezes mais cedo, e os últimos que se acomodavam quando chegávamos aos pousos. Realizaram todo o percurso a pé, utilizando-se algumas vezes de animais adestros. Em resistência, duvidamos que haja raça igual à do sertanejo do nordeste. Dê-se-lhe carne de sol, farinha e rapadura e ele caminhará, à pé, sem desfalecimento, meses a fio, por quaisquer regiões. (grifos meus)
\end{abstract}

Por outro lado, assim como Euclides da Cunha, os autores do relatório enfatizam que os sertanejos "são impermeáveis ao progresso e a civilização", preferindo, antes. a vida primitiva, a inércia e a passiva rotina à qual estavam acostumados a viver (Neiva, Penna, 1984, p.173-174), estando de tal modo afastados da civilização, que é "raro o indivíduo que sabe o que é Brasil". Além disso, o governo era para eles tão somente um homem que exerce autoridade e lhes cobra impostos sobre sua pobre produção. Além do mais, os sertanejos não se viam como parte de uma nação e nem ao menos sabiam o que isso significa, sendo "a única bandeira que conhecem ... a do Divino". Para os homens do sertão nordestino, até mesmo Neiva e Penna pareciam estrangeiros, "gringos ou fidalgos", como os chamavam (p.191).

Do mesmo modo que Euclides da Cunha, os pesquisadores destacam a existência, no Brasil, de duas sociedades distintas, a do litoral e a do sertão. Entretanto, como aponta Nísia Trindade Lima (2007, p.1171), Neiva e Penna interpretam a existência dessas duas sociedades de modo distinto do autor de Os sertões. Enquanto este último assumia que as condições sociais do interior brasileiro foram criadas pelo isolamento em relação ao litoral, aqueles compreenderam que os problemas enfrentados pelo sertanejo diziam respeito ao abandono e à falta de atenção por parte das autoridades políticas e das elites do litoral, o que altera significativamente o sentido político dessa interpretação.

As denúncias e as descrições do sertão feitas por Neiva e Penna ganham significado político ainda mais importante quando analisadas à luz do contexto político e social em que vivia o Brasil durante a Primeira República. De acordo com a historiografia, naquele período o sistema republicano brasileiro estava dominado por amplas oligarquias regionais, que administravam o país a partir de relações políticas excludentes e autoritárias como o coronelismo, o mandonismo e o clientelismo (Leal, 1976; Fausto, 1994; Carvalho, 1998). 
De acordo com José Murilo de Carvalho (1998, p.120), pelo menos até o final da Primeira Guerra Mundial o sistema republicano brasileiro não fez nenhum esforço para incorporar a maioria da população, em especial os negros, mestiços e sertanejos. A própria ideia de povo, ele continua, era puramente abstrata para nossas elites, e, devido à falta de direitos que garantissem a cidadania, o povo era, em sua maioria, hostil ou totalmente indiferente ao sistema republicano. De maneira geral, as denúncias de Neiva e Penna remetiam exatamente à ineficiência desse sistema político que impedia maior intervenção do Estado nas longínquas regiões dominadas pelos coronéis e pelas oligarquias agrárias.

O progresso, a civilização e a integração da nação como comunidade homogênea, consideravam os viajantes, só se tornariam realidade no interior do Brasil quando o governo deslocasse sua atenção para o imenso sertão, abrindo ferrovias e levando, por meio delas, novos imigrantes para colonizar e cultivar o solo sertanejo. Do ponto de vista de Neiva e Penna (1984, p.181), "sem este elemento e sem o auxílio do estrangeiro, [a] cuja iniciativa, operosidade e tirocínio todo o continente americano deve quase todo o progresso que possui, sem este concurso, será inútil, esperar o milagre da transformação do sertão do nordeste na tão anunciada terra de promissão". Para reforçar seu argumento, destacavam o exemplo norte-americano, cujo progresso havia sido construído a partir do esforço do governo em explorar o oeste do país e atrair as massas de imigrantes europeus.

Embora Neiva atribuísse à imigração importante valor civilizacional, já que levaria ao sertão todas as 'benesses' do progresso e da civilização, as ideologias raciais também encontravam seu lugar em seu discurso. Em crônica publicada no início dos anos 20, "Presente de negros", Neiva protestava contra o projeto do governo norte-americano de enviar um grupo de imigrantes negros daquele país para o Brasil, mais especificamente para o estado do Mato Grosso, como amplamente noticiado na imprensa da época. ${ }^{8} \mathrm{Em}$ sua opinião, o consentimento do governo brasileiro a tal proposta soava ultrajante, uma vez que o Brasil já havia encontrado o caminho para solucionar seu problema racial, referindo-se à miscigenação e ao processo de branqueamento em curso no país, conforme ideologia corrente entre parte da intelectualidade brasileira desse período (Skidmore, 1976). Neiva (1927, p.114) citava os trabalhos de Batista Lacerda e Oliveira Lima para destacar que, devido à entrada de novos imigrantes, a população brasileira embranqueceria em menos de um século, sendo inconcebível que novos imigrantes negros fossem aqui recebidos:

Cada qual resolve seus problemas como entende. Nós pensamos ter encontrado a melhor solução. No Brasil nunca houve preconceito de raça .... O senso comum está a nos indicar que devemos evitar, a todo o transe, esse imprudente desafio a futuras e inevitáveis tempestades domésticas que pareciam estar definitivamente afastadas. Caso sejam suscitadas pela presença de uma força catalítica, como seria a vinda de um núcleo de pretos hipersaturados de ódio contra o branco, quem, com segurança, poderá prever o curso dos acontecimentos futuros? (p.118).

Assim, ao mesmo tempo que se preocupava com possível segregação racial e a violência que dela poderia decorrer no Brasil, Neiva parecia temer que a entrada de imigrantes negros viesse a comprometer o processo de branqueamento da população brasileira. Não obstante o fato de negar a existência de preconceito racial no país, esse cronista preferia pensar a formação nacional sem a presença do imigrante negro em nossa identidade. Cabe ressaltar 
que, como deputado federal, integrante da comissão que formulou o projeto de seleção imigratória da Constituinte de 1934, Neiva realizou discursos na plenária da Câmara posicionando-se contrário à entrada de imigrantes negros, assim como de japoneses, uma vez que eram responsáveis pela formação de 'quistos raciais' que não contribuíam para o processo de branqueamento do tipo racial brasileiro (Geraldo, 2007, p.70-73).

No rastro de Euclides da Cunha e da própria historiografia paulista, Arthur Neiva argumentava que o verdadeiro tipo nacional se estava formando no interior do país, longe do contato com o elemento negro. Era no sertão que sobrevivia o mameluco, fruto da união do homem branco, representado pelos bandeirantes, com grupos indígenas. Segundo Neiva, o mameluco constituía um tipo de homem tenaz, resistente e inteligente, a despeito de todas as adversidades do meio, devendo-se a ele atribuir nosso legado racial. Esse tipo de argumento está presente tanto no relatório de viagem de 1916, quanto nas crônicas publicadas ao longo dos anos 20, como já destaquei.

Por outro lado, Neiva enfatizava "o novo caldeamento racial ítalo-brasileiro" que começava a prosperar no interior do estado de São Paulo. O cientista considerava, aliás, a formação racial paulista um elemento fundamental na expansão das fronteiras nacionais, destacando-a como "raça enérgica e conquistadora", que lembrava a força e a tenacidade do homem norte-americano (Neiva, 1927, p.129). De São Paulo, argumentava no início dos anos 20, deveriam "sair bandeiras de outro feitio; não mais aquelas que varando os sertões e devassando novas terras foram formando uma nação quase do tamanho de um continente", mas as bandeiras que conduziriam "os emissários da nova civilização", aqueles que deveriam "galvanizar" outras regiões brasileiras, "cujo progresso tem sido retardado por uma menta-lidade anacrônica e contemplativa" (Neiva, 1940b, p.26). Seguindo a trilha da historiografia paulista, sobretudo de historiadores como Affonso de Taunay e Alfredo Ellis, Neiva ufanava as origens étnicas e o modo como o estado paulista se organizava. Sua célebre frase, que afirmava ser "São Paulo uma locomotiva puxando vinte vagões vazios", não só expressa a importância que ele atribuía ao estado na formação e desenvolvimento do Brasil, como também ajudava a alimentar a construção da identidade paulista.

\section{Considerações finais}

Não obstante seu otimismo em relação ao futuro do país, Neiva compreendia que a "evolução do Brasil" havia chegado num momento decisivo: ou o Brasil seguiria o exemplo do progressivo estado de São Paulo, ou teria que fazer a sua 'Reconstrução', como fizeram os Estados Unidos no século XIX, após a Guerra de Secessão (Neiva, 1927, p.183). Dizia ele, na década de 1920:

Penso que o Brasil chegou a uma encruzilhada, e todos devem falar francamente, a fim de orientar o país no caminho a tomar. Estou convencido de que assistimos a um desses momentos históricos, onde as lutas e competições pessoais, que nos absorvem e devoram, devem amortecer ou cessar, e cada qual concorrer à medida das suas forças com o contingente, embora mínimo, da sua observação, experiência e conhecimento (Neiva, 1927, p.106-107).

Essa reconstrução nacional, em sua opinião, deveria começar na forma de "verdadeira cruzada", contra a mentalidade política das elites dirigentes, pelo abandono dos excessos 
de imaginação, sentimentalismo e superstições, e ampla reforma na educação, na ciência e em nossos códigos de leis. A própria Constituição Federal, observava Neiva, se caracterizava como uma espécie de livro que nenhum respeito infundia às classes dirigentes, servindo apenas para atemorizar o pobre e indefeso "Jeca" (Neiva, 1927, p.188). Com-preendia, enfim, que enquanto o Brasil insistisse em discutir ideias mais do que em agir, em se preocupar com os problemas externos mais do que com os nossos próprios dilemas, continuaria sendo nação condenada pelo analfabetismo, pela fome e pela doença, especialmente no interior, onde o "Jeca" permanecia "esquálido, desnutrido, sem vias de comunicação, sem instrução, esquecido de quase todos os governos, vivendo ao Deus dará" (p.186).

O conteúdo das crônicas de Neiva pode ser visto como projetos político-culturais que propunham reformar os 'caminhos da nação', preocupação central da geração de intelectuais a que ele pertencia. Como intelectual que assumiu o papel de cientista e de homem de ação, Arthur Neiva repudiava o diletantismo, o uso da retórica e do conhecimento enciclopédico praticado pela maioria dos homens de letras, bem como o modo pelo qual as elites dirigentes faziam política no Brasil, desrespeitando os interesses nacionais em nome dos particulares. Em tom de lamento, mas também de ironia, afirmava: "o Brasil só progride à noite, quando os governantes dormem" (Neiva, 1927, p.72). Segundo seu ponto de vista, o mundo de nossas elites não era o Brasil, e nossos interesses não eram os nacionais, uma vez que os grupos responsáveis pelos destinos do país eram desprovidos do sentimento nacionalista e de capacidade política e intelectual. Seguindo o diagnóstico de Alberto Torres (1982), que no início da década de 1910 indicara ser a falta de consciência das elites em relação à realidade do país o principal problema nacional, Arthur Neiva remexia a ferida nacional ao indicar a mentalidade das elites brasileiras o principal entrave à organização do país.

Desse modo, a "comunidade nacional" imaginada por Neiva precisaria ser reinventada sob novos termos. Em vez de seguirmos as tradições intelectuais e o modo de pensar do europeu, especialmente do português e do francês, os referenciais de nossas elites deveriam deslocar-se para a "América", onde, segundo ele, se erigia uma nação moderna e progressiva (Neiva, 1927, p.106). Ao negar o determinismo racial e climático como nossos principais dilemas, recusando as explicações racistas e imperialistas elaboradas pelos cientistas e viajantes estrangeiros para diagnosticar o Brasil, Arthur Neiva acreditava que "a marcha nacional" encontraria seu caminho quando aderisse ao ideário progressista, tal qual vinha sendo empreendido pelos Estados Unidos. Aqui, uma vez mais, a ambivalência do nosso cronista chama a atenção. Não obstante o fato de recusar as tradições europeias e o discurso imperialista sobre o que somos, Neiva acreditava que nosso modelo de sociedade e desenvolvimento nacional deveria ser encontrado a partir dos valores da sociedade norteamericana, sobretudo no que dizia respeito à capacidade de organização política, intelectual e econômica.

De outro lado, porém, a narrativa nacionalista de Neiva encarnava sua própria experiência, posto que o homem sertanejo era por ele transformado numa espécie de herói abandonado, capaz de assumir o papel de regenerador da nação quando bem alimentado e em condições adequadas de saúde, habitação e transporte, como transparece no relatório 
de viagem que produziu com Belisário Penna. Mesmo sendo um entusiasta da imigração e dos valores civilizacionais e progressistas que ela poderia trazer, Neiva entendia que o elemento autenticamente nacional seria formado a partir do interior do país, onde o bravo sertanejo resistia a despeito de todas as adversidades.

\section{NOTAS}

* Este trabalho foi apresentado inicialmente durante a 20a Reunião Anual do Instituto Biológico de São Paulo, em mesa-redonda que debateu a trajetória intelectual, científica e política de Arthur Neiva, coordenada pelo historiador André Felipe Cândido da Silva, a quem agradeço as prestimosas sugestões e a gentileza de ceder alguns importantes documentos utilizados neste artigo. Agradeço também à professora Maria Aparecida Mota, do Programa de Pós-Graduação em História Social da UFRJ, a leitura do texto e as sugestões apresentadas ao longo do curso "Interpretações do Brasil: em busca de uma identidade nacional", ministrado no segundo semestre de 2007.

${ }^{1}$ A principal característica de Arthur Neiva, de acordo com um de seus biógrafos, César Pinto (1932), era exatamente sua atuação como 'cientista e homem público'. De fato, Neiva ocupou-se tanto dos serviços de administração pública e da política nacional quanto da atividade intelectual e científica, especialmente no campo da entomologia, em que desenvolveu boa parte de seus trabalhos científicos. Palavras semelhantes, e carregadas de elogios, foram ditas pelo escritor Monteiro Lobato (1956), para quem Neiva representava a figura de um homem moderno que "fazia ciência à moda de Oswaldo Cruz", transformando ideias em ação.

${ }^{2}$ Arthur Neiva nasceu em Salvador, Bahia, em 1880. Embora tenha começado seus estudos universitários na Faculdade de Medicina da Bahia, concluiu-os na Faculdade de Medicina do Rio de Janeiro, em 1903. Dois anos depois, ingressou no Instituto de Manguinhos, sendo nomeado por Oswaldo Cruz como auxiliar técnico do Laboratório Bacteriológico, onde executou trabalhos especialmente na área da entomologia. Após realizar expedições científicas pelo interior do Brasil, viajar pelos Estados Unidos e Europa e atuar no Instituto Bacteriológico de Buenos Aires entre 1915 e 1916, foi contratado pelo governo de São Paulo como diretor do Serviço Sanitário do Estado, ocasião em que elaborou o primeiro código sanitário brasileiro. Ainda em São Paulo, ficou conhecido pela campanha que realizou contra a broca-do-café, praga que ameaçava a produção de todo o estado. Atuou entre 1923 e 1927 como diretor do Museu Nacional do Rio de Janeiro e, posteriormente, como diretor do Instituto Biológico de São Paulo. No campo político, foi interventor da Bahia em 1931 e eleito representante de seu estado na Assembleia Nacional Constituinte de 1933, onde se ocupou, especialmente, da questão da saúde pública e do debate sobre imigração e colonização do território nacional (Borgmeier, 1940; Lent, 1943; Silva, 2006).

${ }^{3}$ Embora não seja objeto de análise deste trabalho, vale ressaltar que, em 1940, Arthur Neiva publicou, pela Editora Brasiliana, importante obra literária sobre a influência da língua tupi no vocabulário brasileiro, na qual reuniu artigos publicados no Jornal do Commercio a partir do final dos anos 30 (Neiva, 1940a).

${ }^{4}$ Arthur Neiva correspondeu-se com Monteiro Lobato de 1918 até sua morte, em 1943. As dezenas de cartas que trocaram encontram-se no Arquivo Pessoal Arthur Neiva, sob a guarda do Centro de Pesquisa e Documentação de História Contemporânea do Brasil, da Fundação Getulio Vargas (CPDOC/FGV). Sobre essa correspondência, consultar também o livro do historiador e critico literário Cassiano Nunes (1981), com levantamento sobre os principais assuntos tratados.

${ }^{5}$ A Revista do Brasil foi criada em janeiro de 1916 pelo chamado grupo de O Estado de São Paulo, do qual participavam Júlio de Mesquita, Plínio Barreto, Pinheiro Junior e Alfredo Pujol. Estimulados pelo nacionalismo que mobilizou parte dos intelectuais brasileiros durante o período da Primeira Guerra Mundial, esses homens de letras se propuseram a promover amplo debate sobre a realidade nacional, procurando construir um núcleo de propaganda nacionalista e, ao mesmo tempo, estimulando a organização de um plano de ação política para sanear os 'males nacionais' (Luca, 1999).

${ }^{6}$ Para o historiador Eric Hobsbawm (1998), o entre-guerras foi marcado no mundo todo pela ascensão de um novo nacionalismo, que estimulou a formação das identidades nacionais e o fortalecimento dos Estados. Para Hobsbawm, esse contexto se formou, por um lado, pela existência de 'minorias oprimidas' que buscavam preservar suas identidades culturais, étnicas e políticas em territórios que eram politicamente multinacionais e, por outro, pelo fato de o modelo de civilização e organização nacional europeu passar a ser questionado após o trágico desfecho da Primeira Guerra Mundial. No Brasil, como destacou Boris Fausto (1994), esse período foi marcado por nacionalismo mais realista - em contraposição ao 
nacionalismo romântico típico do final do século XIX e início do XX -, formado pela ascensão de novos grupos profissionais de classe média, que ansiavam reformar a política tradicional da República e lançar o Brasil como nação social e economicamente viável aos olhos do mundo.

${ }^{7}$ Vale destacar que, após divulgado, a repercussão do relatório de viagem foi imediata, o que possibilitou o aparecimento de grande número de artigos na imprensa em tom de denúncia contra as péssimas condições sanitárias e a abundância de doenças que assolava a população interiorana. Como resultado das denúncias do relatório, o Brasil passou a ser visto como "um imenso hospital", segundo o médico carioca Miguel Pereira ainda nos anos 10, sendo o Jeca Tatu, de Monteiro Lobato, tomado como a própria personificação do homem sertanejo. Tal como a historiografia tem apontado, todo o movimento em prol do 'saneamento do Brasil' - campanha que mobilizou grande número de médicos, cientistas e intelectuais a partir do final dos anos 10 e que culminou com a criação do Departamento Nacional de Saúde Pública em 1920 - tem suas origens no efeito que o relatório causou no meio intelectual e político, sobretudo no Rio de Janeiro e em São Paulo (Castro-Santos, 1985; Lima, Hochman, 1996; Hochman, 1998; Lima, 1999).

${ }^{8}$ Vale destacar que, como deputado federal, Arthur Neiva foi uma das lideranças importantes na elaboração do projeto de imigração aprovado pela Assembleia Nacional Constituinte de 1933-1934. Ao lado dos deputados Pacheco e Silva, Miguel Couto, Xavier de Oliveira e Monteiro de Barros, lutou pela aprovação de legislação que definia a política imigratória a partir do sistema de cotas raciais, permitindo a entrada de apenas $2 \%$ do número de imigrantes existentes no Brasil, nos últimos 50 anos. Na prática, o sistema de cotas favorecia, por um lado, principalmente os imigrantes europeus, uma vez que, entre 1880 e 1930, o maior contingente de imigrantes a aportar no Brasil havia sido de portugueses, italianos, espanhóis e alemães e, por outro, possibilitava maior controle sobre a imigração de japoneses e africanos, vista por muitos como 'perigosa' para a futura homogeneização da 'raça nacional' (Carneiro, 1988; Geraldo, 2007).

\section{REFERÊNCIAS}

ANDERSON, Benedict.

Nação e consciência nacional. São Paulo: Ática. 1989.

AZEVEDO, Fernando.

As ciências no Brasil. In: Azevedo, Fernando (Org.). As ciências no Brasil. v.1. Rio de Janeiro: Editora UFRJ. p.5-12. 1994.

AZEVEDO, Fernando.

A cultura brasileira. 4.ed. Brasília: Editora da UNB. 1963.

BORGMEIER, Thomas.

Arthur Neiva: a propósito do seu $60^{\circ}$ aniversário natalício. Revista de Entomologia, Rio de Janeiro, v.11, n.1-2, p.1-104. 1940.

BRITO, Nara.

Oswaldo Cruz: a construção de um mito na ciência brasileira. Rio de Janeiro: Editora Fiocruz. 1995.

CARNEIRO, Maria Lucia Tucci.

$O$ anti-seminismo na era Vargas: fantasmas de uma geração (1930-1945). São Paulo: Brasiliense. 1988.

CARVALHO, José Murilo de.

História intelectual no Brasil: a retórica como chave de leitura. Topoi: Revista de História, Rio de Janeiro, n.1, p.123-152. 2002.

CARVALHO, José Murilo de. Brasil 1870-1914: a força da tradição.
In: Carvalho, José Murilo de. Pontos e bordados: escritos de história e política. Belo Horizonte: Editora da UFMG. p.107-129. 1998.

CASTRO-SANTOS. Luiz Antonio de. O pensamento sanitarista na Primeira República: uma ideologia de construção da nacionalidade. Dados - Revista de Estudos Sociais, Rio de Janeiro, v.28, n.2, p.193-210. 1985.

CUNHA, Euclides da.

Os sertões. 22.ed. Rio de Janeiro: Livraria

Francisco Alves. 1.ed., 1902. 1952.

FAUSTO, Boris.

História do Brasil. São Paulo: Editora Edusp. 1994.

GERALDO, Endrica.

$O$ 'perigo alienígena': política imigratória e pensamento racial no governo Vargas (1930-1945). Tese (Doutorado) - Universidade Estadual de Campinas, São Paulo. 2007.

HERSCHMANN, Micael; PEREIRA, Carlos A.

Messeder.

O imaginário moderno no Brasil. In:

Herschmann, Michael; Pereira, Carlos A.

Messeder (Org.). A invenção do Brasil moderno: medicina, educação e engenharia nos anos 20-30. Rio de Janeiro: Rocco. p.9-42. 1994.

HOBSBAWM, Eric.

Nações e nacionalismo desde 1780: programa, mito e realidade. Rio de Janeiro: Paz e Terra. 1998. 
HOCHMAN, Gilberto.

A era do saneamento: as bases da política de saúde pública no Brasil. São Paulo: Hucitec. 1998.

HOLANDA, Sérgio Buarque de.

Raízes do Brasil. São Paulo: José Olympio. 1.ed., 1936. 1984.

LEAL, Vitor Nunes.

Coronelismo, enxada e voto. 3.ed. São Paulo:

Alfa-Omega. 1976.

LIMA, Nísia Trindade.

Public health and social ideas in modern Brazil. American Journal of Public Health, Washington DC, v.97, n.7, p.1168-1177. 2007.

LIMA, Nísia Trindade.

Um sertão chamado Brasil: intelectuais e representação geográfica da identidade nacional. Rio de Janeiro: Revan. 1999.

LIMA, Nísia Trindade; HOCHMAN, Gilberto. Condenado pela raça, absolvido pela medicina: o Brasil descoberto pelo movimento sanitarista da Primeira República. In: Maio, Marcos Chor; Santos, Ricardo Ventura (Org.). Raça, ciência e Sociedade. Rio de Janeiro: Editora Fiocruz. p.2340. 1996.

\section{LENT, Herman.}

In memoriam: Arthur Neiva. Revista Brasileira de Biologia, Rio de Janeiro, v.3, n.3, p.273-291. 1943.

LOBATO, Monteiro.

Arthur Neiva. In: Mr. Slang e o Brasil e Problema vital. São Paulo: Brasiliense. p.169-175. 1956.

LUCA, Tânia Regina de.

A Revista do Brasil: um diagnóstico para a (n)ação. São Paulo: Editora da Unesp. 1999.

NEIVA, Arthur.

Estudos da língua nacional. São Paulo:

Brasiliana. 1940a.

NEIVA, Arthur.

Serviço sanitário de São Paulo. In: Neiva,

Arthur. Collectânea. Rio de Janeiro: s.n. 1940b.

NEIVA, Arthur.

Correspondência a Monteiro Lobato. Arquivo

Arthur Neiva (Centro de Pesquisa e

Documentação de História Contemporânea do Brasil/Fundação Getulio Vargas). 13 mar. 1934.

NEIVA, Arthur.

Correspondência a Monteiro Lobato. Arquivo Arthur Neiva (Centro de Pesquisa e

Documentação de História Contemporânea do Brasil/Fundação Getulio Vargas). 21 jan. 1929.

NEIVA, Arthur.

Daqui e de longe...: crônicas nacionais e de

viagem. São Paulo: Cia. Melhoramentos. 1927.
NEIVA, Arthur

Correspondência a Sampaio. Arquivo Arthur Neiva (Centro de Pesquisa e Documentação de História Contemporânea do Brasil/Fundação Getulio Vargas). 9 mar. 1918.

NEIVA, Arthur

Correspondência a Afrânio Peixoto. Arquivo Arthur Neiva (Centro de Pesquisa e

Documentação de História Contemporânea do Brasil/Fundação Getulio Vargas). 20 jul. 1917.

NEIVA, Arthur; PENNA, Belisário.

Viagem científica pelo norte da Bahia, sudoeste de Pernambuco, sul do Piauí e de Norte a sul de Goiás. Brasília: Academia Brasileira de Letras. 1.ed., 1916. 1984.

NUNES, Cassiano.

O patriotismo difícil: a correspondência entre Monteiro Lobato e Arthur Neiva. São Paulo: Copidart. 1981.

OLIVEIRA, Lucia Lippi.

A questão nacional na Primeira República. São Paulo: Brasiliense. 1990.

PINTO, César.

Arthur Neiva: cientista e homem público. Revista Médico-Cirúrgica do Brasil, Rio de Janeiro, ano 11, n.1, p.3-11. 1932.

ROQUETTE-PINTO, Edgard.

A inquietação artística de Roquette Pinto. Vamos Ler, Rio de Janeiro. 23 mar. 1939.

SÁ, Dominichi Miranda de.

A ciência como profissão: médicos, bacharéis e cientistas no Brasil (1895-1935). Rio de Janeiro: Editora Fiocruz. 2006.

SEVCENKO, Nicolau.

A literatura como missão: tensões sociais e criação cultural na Primeira República. São Paulo: Brasiliense. 1999.

SILVA, André Felipe Cândido da.

A campanha contra a broca-do-café em São Paulo (1924-1927). História, Ciências, Saúde Manguinhos, Rio de Janeiro, v.13, n.4, p.857993. 2006.

\section{SKIDMORE, Thomas.}

Preto no branco: raça e nacionalidade no pensamento brasileiro. São Paulo: Paz e Terra. 1976.

TAUNAY, Affonso de.

Duas palavras de desvaliosa apresentação. In: Neiva, Arthur. Daqui e de longe...: crônicas nacionais e de viagem. São Paulo: Editora Cia. Melhoramentos. p.3-12. 1927.

TORRES, Alberto.

O problema nacional brasileiro. 4.ed. São Paulo: Companhia Editora Nacional. 1.ed., 1914. 1982. 